\title{
Follow-up after Ductal Carcinoma In Situ Treatment
}

\author{
Nicolae Gica ${ }^{1,2}$, Laura Mihaela Mustata ${ }^{2}$, Gheorghe Peltecu ${ }^{1,2^{*}}$, Anca Maria Panaitescu ${ }^{1,2}$ \\ "Carol Davila" University of Medicine and Pharmacy, Bucharest, Romania \\ 2"Filantropia" Clinical Hospital, Bucharest, Romania
}

*Corresponding author: Gheorghe Peltecu, MD, PhD, FACS Professor of Obstetrics and Gynecology

"Carol Davila" University of Medicine and Pharmacy, Bucharest, Romania "Filantropia" Clinical Hospital

Bucharest, Romania

E-Mail: gheorghe.peltecu@gmail.com

\section{Rezumat}

Supravegherea după încheierea tratamentului carcinomului ductal in situ (CDIS) este o problemă dezbătută iar o strategie specifică nu a fost încă adoptată. Strategia de urmărire actuală nu se distinge de cea a cancerelor invazive ale sânului. Deşi în ultimii ani CDIS este văzut ca o categorie distinctă de cancer mamar, strategia de urmărire nu reflectă această paradigmă. Se continuă aceeaşi strategie ca şi în cancerul mamar invaziv iar practicile diferă mult în lume dar şi în aceeaşi țară. Stabilirea unui consens este necesară pentru siguranța pacientei şi diminuarea costurilor, fără a compromite rezultatele.

Cuvinte cheie: carcinom ductal in situ, tratament, supraveghere

Key words: ductal carcinoma in situ, treatment, follow-up 


\section{Introduction}

Treated DCIS (surgery, radiation therapy, endocrine therapy) is recognized to have an excellent prognosis with 10 years survival of 98\% (1). Post-treatment surveillance of DCIS has the aim to early recognize and treat any recurrence or a second primary breast cancer, together with the detection of symptoms suggesting metastatic spread or complications related to previous oncologic therapy.

A standard follow-up protocol is based on medical history, physical examination, and mammography. Early detection of a recurrence, be it in situ or invasive, makes its treatment potentially curable.

An important paper was published about the investigation of variations of surveillance practice after surgery for DCIS detected by screening (2). The questionnaire sent by Sloane Project to 74 participating UK breast screening centers included questions about frequency and duration of clinical and mammographic follow-up, if the protocol was respected or if there were variations and what were their reasons, and finally if the centers considered clinical follow-up to be useful.

The results showed wide variations in UK practice. Clinical follow-up visits were recommended from once every 3 months to once a year for 5 years, or 10 years or indefinitely. Mammography follow-up was recommended once a year or every 2 years, without a time limit.

There were hospitals performing follow-up mammography for patients with reconstructed breasts.

Analyzing the health care value, 31 centers considered clinical follow-up of treated DCIS to be of value or of limited value, whereas 28 considered it to have no value (2).

\section{Discussions}

Although there is a high number of cases of treated DCIS worldwide, there are no published guidelines to reflect a common attitude on post-treatment follow-up. Most of the existing guidelines are not evidence based, because there are few high-quality studies of follow-up, analyzing methods of choice, frequency, and duration.

The UK and the European guidelines recommend clinical examination for the first 5 years after primary treatment and mammography once a year or every two years, for at least 5 years (3).

The Australian National Breast Cancer Centre recommends mammography and clinical examination once a year, with mammography performed indefinitely.

The American College of Radiology (ACR), the American College of Surgeons (ACS) and the Society of Surgical Oncology (SSO) published a common guideline on DCIS, recommending clinical examination every 6 months for the first 5 years and then every year (4).

The North American guidelines are even more complex. They recommend mammography even in the early postoperative period to detect possible remaining microcalcifications, then a baseline mammography at 6 to 12 months after completion of radiation therapy, and then an annual mammography. The reason offered as explanations is that most of the local recurrences following wide local excision are detected in the first 1-2 years post-treatment, when clinical palpation is in the normal range $(5,6)$.

In a systematic review of the literature Montgomery DA et al., try to find out if routine clinical examination improves the outcome (7). The aim of the survey was to establish the proportion of locoregional recurrences, possibly treatable, detected by clinical examination, patient self-examination and mammography.

There is a significant difference between detection before and after the year 2000 . Before the year 2000, 30 to $40 \%$ of all recurrences, with potential to be treated, were identified by patients themselves, whereas after the year 2000 , only $15 \%$ of all recurrences were detected by clinical examination.

The accuracy of mammography was higher after the year 2000 therefore the rate of 
detection that was $15 \%$ before the year 2000 became $40 \%$ after 2000 .

Clinical examination detects fewer potentially treatable recurrences, and the detections are late, compared with mammography (7).

Another important conclusion of the study was that patients with clinically detected ipsilateral breast recurrences have a less good prognosis compared to those with recurrences detected by mammography or self-examination. In terms of survival, there is no proof that clinical examination is associated with any advantage.

While most of the studies and metaanalysis show that clinical examination has a low accuracy in detecting early recurrences, most of the societies producing guidelines in Europe (NICE) and North America (ASCO) are recommending it on an annually basis.

Survival is strongly influenced by early detection of locoregional recurrence (8-12). A locoregional recurrence is defined as a recurrence at the level of the ipsilateral breast or axilla. Locoregional recurrence could be detected after mastectomy or after conservative breast surgery.

Recurrence after mastectomy for DICS is easier to be detected by clinical examination, while mammography has a much smaller or no role. On the contrary, mammography plays an important role in the detection of early recurrence after breast conserving surgery.

Follow-up after treated DCIS is important both for medical and economic aspects. Financial services in the health system are very interested in the frequency of clinical examinations and mammograms because they cost money. It is estimated that if follow-up is limited to 5 years, the cost saving will be estimated to 3,7 mil sterling pounds (13), while if it would be limited to 3 years the cost saving would be 9,3 mil sterling pounds.

The European (NICE) and North American (ASCO) guidelines are recommending clinical examination in the first 3 to 5 years after treatment of DCIS. The highest incidence of recurrences is registered between the $2^{\text {nd }}$ and the $3^{\text {rd }}$ year, and its value is $3 \%$, while the incidence rate drops to $2 \%$ after the $3^{\text {rd }}$ year and remains constant for the next 10 years.

If we analyze the treatable recurrences, their incidence is 1-1.5\%/year and stay constant for the next 10 years (14) suggesting that stopping clinical examination after 3 years of follow-up has no scientific justification.

If we analyze the incidence of ipsilateral recurrences detected by clinical examination after conservative surgery, it can be seen that it is only $13 \%$ over a long period of follow-up $(14,15)$.

Clinically detected recurrences are later detected, have a worse prognosis, and have a lesser survival rate compared with patients detected by mammography.

The importance of mammography in the early detection of treatable recurrences after conservative treatment of DCIS is revealed by a study performed in Edinburgh. The increase of incidence from $31 \%$ before the year 2000 (16), to $46 \%$, after the year 2000 , represent a strong support for mammography as an important instrument for follow-up (14). The technical qualities of mammography machines were much improved, and a better-quality assurance was implemented. This study showed that, due to its qualities, mammography detects 5.3 new cancers/1000 screening mammograms performed for follow-up after treated DCIS, having almost the same accuracy of detection as the national screening program.

Axillary recurrence is uncommon, and mammography has a minor role in this detection. To detect such a rare recurrence, it is better that patient to be taught to selfexamine.

\section{Conclusion}

Studies and guidelines showed that there is no consensus concerning frequency and duration of follow-up for post-treated DCIS. The lack of consensus also refers to the means of detection, mammography, clinical examination, or self-examination.

Mammography better detects early recurrence after conservative surgery, while clinical examination those after mastectomies. 
Self-examination seems to better detect isolated axillary recurrences. The impact of mammography is related to technical improvement associated with better protocols of quality assurance. It detects earlier recurrences, when these have a better chance to be treatable, thus improving survival.

In terms of frequency, clinical examination varies, but the most frequent recommendation suggests once every 3 months in the first year, and once a year afterwards, the most common duration of follow-up being 10 years. The value of clinical follow-up to detect recurrences after treatment of DCIS is uncertain or low. Most of the studies showed that the detection is late, compared to mammography, and the better the prognosis, the earlier the detection.

Mammography is recommended to be performed annually. The duration of examinations is not stated precisely but 10 years is frequently mentioned.

There is a need for good quality guidelines for follow-up after treatment of DCIS. These guidelines must be based on good quality research and audit, need consensus, and must be cost efficient.

\section{Conflict of Interest}

The authors declare no conflicts of interests.

\section{References}

1. Elshof LE, Schaapveld M, Schmidt MK, Rutgers EJ, van Leeuwen FE, Wesseling J. Subsequent risk of ipsilateral and contralateral invasive breast cancer after treatment for ductal carcinoma in situ: incidence and the effect of radiotherapy in a population-based cohort of 10,090 women. Breast
Cancer Res Treat. 2016;159(3):553-63.

2. Maxwell AJ, Evans AJ, Carpenter C, Dobson HM, Kearins 0, Clements K, et al. Follow-up for screen-detected ductal carcinoma in situ: results of a survey of UK centers participating in the Sloane project. Eur J Surg Oncol. 2009;35(10):1055-9.

3. National Institute of Health and Clinical Excellence (2009). Early and locally advanced breast cancer: diagnosis and treatment. www.nice.org.uk/ nicemedia/pdf/CG80FullGuideline.pdf.

4. Morrow M, Strom EA, Bassett LW, Dershaw DD, Fowble B, Harris JR, et al. Standard for the management of ductal carcinoma in situ of the breast (DCIS). CA Cancer J Clin. 2002;52(5):256-76.

5. Liberman L, Van Zee KJ, Dershaw DD, Morris EA, Abramson AF, Samli B. Mammographic features of local recurrence in women who have undergone breast-conserving therapy for ductal carcinoma in situ. AJR Am J Roentgenol. 1997;168(2):489-93.

6. Pinsky RW, Rebner M, Pierce LJ, Ben-David MA, Vicini F, Hunt KA, et al. Recurrent cancer after breast-conserving surgery with radiation therapy for ductal carcinoma in situ: mammographic features, method of detection, and stage of recurrence. AJR AJR Am J Roentgenol. 2007;189(1):140-4.

7. Montgomery DA, Krupa K, Cook TG. Follow-up in breast cancer: does routine clinical examination improve outcome? A systematic review of the literature. Br J Cancer. 2007;97(12):1632-41.

8. Dalberg K, Mattsson A, Sandelin K, Rutqvist LE. Outcome of treatment for ipsilateral breast tumour recurrence in early-stage breast cancer. Breast Cancer Res Treat. 1998;49(1):69-78.

9. Clark DH, Le MG, Sarrazin D, Lacombe MJ, Fontaine F, Travagli JP, et al. Analysis of loco-regional relapses in patients with early breast cancers treated by excision and radiotherapy: experience of the Institut GustaveRoussy. Int J Radiat Oncol Biol Phys. 1985;11(1):137-45.

10. Fowble B, Solin LJ, Schultz DJ, Rubenstein J, Goodman RL. Breast recurrence following conservative surgery and radiation: patterns of failure, prognosis, and pathological findings in mastectomy specimens with implications for treatment. Int J Radiat Oncol Biol Phys 1990 Oct;19(4):833-42.

11. Haffty BG, Fischer D, Beinfield M, McKhann C. Prognosis following local recurrence in the conservatively treated breast cancer patient. Int $\mathrm{J}$ Radiat Oncol Biol Phys. 1991;21(2):293-8.

12. Kurtz JM, Spitalier J-M, Almaric R, Brandone H, Ayme Y, Jacquemier J, et al. The prognostic significance of late local recurrenceafter breast conserving therapy. Int J Radiat Oncol Biol Phys. 1990;18(1):87-93.

13. National Institute for Clinical Excellence (2002) Guidance on Cancer Services: Improving Outcomes in Breast Cancer. Manual Update.http://www. nice.org.uk/page.aspx?01/4csgbcguidance Ref Type: Internet Communication

14. Montgomery DA, Krupa K, Jack WJL, Kerr GR, Kunkler IH, Thomas J, et al. Changing pattern of the detection of loco-regional relapse inbreast cancer: the Edinburgh experience. Br J Cancer. 2007;96(12):1802-7.

15. van der Sangen MJC, van de Poll-Franse LV, Roumen RMH, Rutten HJT, Coebergh JWW, Vreugdenhil G, et al. The prognosis of patients with local recurrence more than five years after breast conservation therapy for invasive breast carcinoma. Eur J Surg Oncol. 2006;32(1):34-8.

16. Jack WJL, Kerr GR, Kunkler IH. Long-term follow-up after breast conservation: The Edinburgh experience. Breast. 1998;7: 80-84. 